\title{
DATING BULK SEDIMENTS FROM LIMNIC DEPOSITS USING A GRAIN-SIZE APPROACH
}

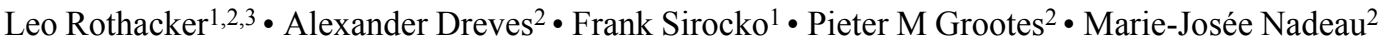

ABSTRACT. Radiocarbon measurements on bulk subaqueous sediments typically provide ages significantly older than actual time of deposition. This is generally caused by the presence of reworked organic compounds, which are depleted in ${ }^{14} \mathrm{C}$. To explore this issue of age heterogeneity, we collected 4 organic-rich samples from varying depths in a lake sediment core at the Gemündener Maar (Eifel, Germany), a lake of volcanic origin. We divided each sample into 5 standard grain-size fractions: gravel, sand, silt, clay, and 1 fraction smaller than $0.45 \mu \mathrm{m}$. These were cleaned separately using a standard acid-alkaliacid treatment. The highly organic gravel-size fraction provided the youngest ${ }^{14} \mathrm{C}$ ages of all grain-size fractions and seems to be associated most closely with the time of deposition. By contrast, the silt and clay fractions show significantly older ages. If the investigated limnic sediment layer does not contain any identifiable terrestrial macrofossils, extracting and measuring coarser grain-size fractions instead of measuring bulk sediment samples will provide a better approximation of the time of sedimentation.

\section{INTRODUCTION}

Lake sediments are comprehensive archives for climate and environmental changes in the past. Therefore, an accurate dating method for sediments is of great importance. Radiocarbon measurements on bulk limnic sediments typically provide ages significantly older than actual time of deposition (Sirocko et al. 2013). As early as 1951, Godwin (1951) discussed sources of error in dating bulk sediments from limnic deposits. He stated that ages, much younger than the actual time of deposition, can be caused by secondary incorporation of more recent organic matter into old deposits, for instance by roots, burrowing animals, moving water, or bacterial activity. Ages significantly too old may result from the introduction of ${ }^{14} \mathrm{C}$-depleted carbon derived from ancient limestones (the "hardwater effect"), peaty environments, as well as erosion processes. At present, many possible sources of error are known, but there are no universal solutions for the detection and correction of erroneous ${ }^{14} \mathrm{C}$ dates from bulk limnic sediments (MacDonald et al. 1991). Based on this recognition, it was recommended to date macro-remains, such as twigs, instead of bulk sediment (Sirocko et al. 2013). However, macro-remains are not present throughout each limnic sediment core. Other environments, such as terrestrial soils, may likewise show a large age heterogeneity (e.g. Rethemeyer 2004; Rethemeyer et al. 2004; Dreves 2008), both in chemical fractions and in grain sizes, where smaller grain sizes, especially clay, provide ${ }^{14} \mathrm{C}$ ages significantly older than coarser grain-size fractions (Scharpenseel and Becker-Heidmann 1992; Schöning and Kögel-Knabner 2006). Abbott and Stafford (1996) measured ${ }^{14} \mathrm{C}$ activities from different reservoirs including various chemical fractions derived from limnic systems, soils, and peats. They suggested to preferably date discrete terrestrial plant fossils, carefully inspected for signs of reworking, or if absent, humic acid fractions, to achieve reliable results. The definition of a reliable humic acid fraction is, however, a problem of similar complexity to the definition of a reliable sediment fraction. The reliability of total humic acid dates is questionable in view of their mobility with groundwater (e.g. Hiller et al. 2003). Other studies proposed a combustion procedure at low temperatures for all bulk sediment environments to avoid carbon associated with clay minerals (McGeehin et al. 2001). Considering and recognizing the previous work, we focus on dating organic material associated with different grain sizes selected

\footnotetext{
${ }^{1}$ Institute of Geosciences, Johannes Gutenberg University, J-J Becher Weg 21, 55128 Mainz, Germany.

${ }^{2}$ Leibniz Laboratory for Radiometric Dating and Isotope Research, Christian Albrechts University, Max-Eyth-Str. 11-13, 24118 Kiel, Germany.

${ }^{3}$ Corresponding author. Email: leorothacker@gmail.com.
} 


\section{Rothacker et al.}

from limnic bulk sediments, to verify whether there is a relationship between ${ }^{14} \mathrm{C}$ ages and grain size. The working hypothesis is that coarser, less mobile organic particles are more likely to be linked to the deposition event. For this investigation, we chose the Gemündener Maar sediment core as a case study. The core derives from a lake of volcanic origin, where emission of volcanic gases is common, even if the volcano has been "inactive" for thousands of years. Volcanic $\mathrm{CO}_{2}$ is depleted in ${ }^{14} \mathrm{C}$ and could, when incorporated by flora and fauna, result in ages much older than the time of growth and deposition, also on land (Bruns et al. 1980).

\section{METHODS}

Four sediment samples were taken from an 8-m-long core drilled at $\sim 20 \mathrm{~m}$ water depth near the center of the Gemündener Maar $\left(6^{\circ} 50^{\prime} \mathrm{E}, 50^{\circ} 11^{\prime} \mathrm{N}\right)$ in the Eifel region of Germany. The lake fills the crater left in the local Devonian siltstone (greywacke) by an explosive eruption of the Eifel volcanic field during the last glacial period. This sediment core is part of the Eifel Laminated Sediment Archive (ELSA) project at the University of Mainz. Samples were chosen for lamination, dark color, i.e. high carbon content, and absence of mold. Only 1 (KIA-46836) out of 4 samples showed a significant lamination. Furthermore, 2 recent tree buds growing close to the shore of the investigated lake have been collected to check the influence of volcanic gases on $\mathrm{CO}_{2}$ incorporated by the local flora. The tree buds were obtained south (growing directly above the water surface) and southeast of the lake (20 $\mathrm{m}$ away from the shore).

Macro-remains (if present) were first collected from the sediment samples in order to date them separately to achieve the most reliable age for the deposition event. Two out of 4 samples provided plant remains of terrestrial origin, large enough in size and weight to ${ }^{14} \mathrm{C}$ date. One has been identified as a leaf fragment from a willow tree (KIA-46834), the second as a terrestrial twig (KIA-46833) that had just started growing. The sediment samples were then split into 4 standard grain-size fractions: gravel ( $>2 \mathrm{~mm})$; sand $(2 \mathrm{~mm}-0.063 \mathrm{~mm})$; silt $(0.063 \mathrm{~mm}-2 \mu \mathrm{m})$; clay $(<2 \mu \mathrm{m})$; and 1 fraction smaller than $0.45 \mu \mathrm{m}$ containing colloidal particles and truly dissolved organic carbon. All size fractions contain a mixture of minerogenic material and organic remains, of which the organic material is targeted for ${ }^{14} \mathrm{C}$ dating. For KIA-46833 and KIA-46834, the plant remains described above were dated for the gravel-sized fraction, whereas the other 2 gravel fractions consist of an unidentifiable mineral-organic mixture collected on a standard 2-mm sieve. The sediment passing the 2-mm sieve was treated with ultrasound at an energy input of $60 \mathrm{~J} \mathrm{~mL}^{-1}$ in order to break up macro-aggregates (Amelung et al. 1998), and afterwards sieved to $0.063 \mathrm{~mm}$ to obtain the sand fraction. All material that passed the $0.063-\mathrm{mm}$ sieve (silt and clay) was then again treated with ultrasound; otherwise, macro-aggregates could falsely contribute to bigger grain sizes. An energy input of $440 \mathrm{~J} \mathrm{~mL}^{-1}$ was used, as suggested by Amelung et al. (1998). The separation of silt and clay was achieved using a centrifuge at $\sim 650 \mathrm{~g}$ for $1 \mathrm{~min}$. This process was repeated until the supernatant was clear. Finally, part of the clay fraction was washed on a precombusted $0.45-\mu \mathrm{m}$ silver filter to obtain the smallest, colloidal grain-size fraction. The gravel, silt, sand, and clay fraction and the 2 modern buds were mechanically cleaned under the microscope (e.g. remove visible roots) and then subjected to an acid-alkali-acid (AAA) treatment (Grootes et al. 2004) to remove carbonates and soluble contaminants. The fraction $<0.45 \mu \mathrm{m}$ was only acidified with $1 \% \mathrm{HCl}$ to remove carbonates. The ${ }^{14} \mathrm{C}$ concentration of the carbon of each chemically cleaned sample fraction was determined using the $3 \mathrm{MV}$ HVE accelerator mass spectrometry system (AMS) at the Leibniz Laboratory for Radiometric Dating and Isotope Research (Nadeau et al. 1997, 1998). ${ }^{14} \mathrm{C}$ ages are expressed in percent modern carbon (pMC) following Stuiver and Polach (1977). 


\section{Dating Bulk Sediments Using Grain-Size Approach}

\section{RESULTS AND DISCUSSION}

Four organic-rich samples from the Gemündener Maar sediment core, each divided into 5 grain-size fractions, were processed in order to test our working hypothesis that coarser, less mobile organic particles are more likely of primary deposition and thus, in ${ }^{14} \mathrm{C}$ measurement, give more reliable results for the deposition chronology. In addition, 2 vegetation samples were taken to test for the influence of volcanic $\mathrm{CO}_{2}$, escaping from the lake, on the vegetation around it.

Bruns et al. (1980) investigated the lake Laacher See ( $\sim 25 \mathrm{~km}$ from Gemündener Maar) where the escape of $\mathrm{CO}_{2}$ is visible on the water surface. They measured the ${ }^{14} \mathrm{C}$ concentration of terrestrial plants at varying distances (and heights) from the lake shore. The results indicate that plants growing close to the gaseous emanations provide lower ${ }^{14} \mathrm{C}$ activities than plants growing farther away. Considering this, 2 tree buds growing S/SE of Gemündener Maar lake were obtained in February 2012. The prevailing wind pattern in the Eifel region is W/NW. Volcanic $\mathrm{CO}_{2}$, if any, thus could have influenced the downwind vegetation S/SE of the lake shore. The modern tree bud samples were measured at $104.73 \pm 0.29$ and $104.15 \pm 0.29 \mathrm{pMC}$. The ${ }^{14} \mathrm{CO}_{2}$ concentration of air was measured by Ingeborg Levin, Heidelberg University, in Schauinsland (Germany), $300 \mathrm{~km}$ south from Gemündener Maar. Her result for January 2012 is 104.14 pMC (I Levin, personal communication), proving that at present there is no evidence of depletion in ${ }^{14} \mathrm{C}$ in terrestrial plants near the Gemündener Maar lake. However, this may have been different in the past.

Results of ${ }^{14} \mathrm{C}$ measurements of all 4 samples, each divided into 5 grain-size fractions, are summarized in Table 1 and Figure 1. Eight samples were measured in duplicate on targets prepared from the same $\mathrm{CO}_{2}$. Of these, 3 differed by less than $1 \sigma$ and 4 between 1 and $2 \sigma$; for these, average values are listed. The duplicate dates for the clay of KIA- 46834 differed by $2.8 \sigma$ and are both listed. This confirms the general reliability of the measurements, although the real variability is somewhat larger than indicated by the calculated standard deviation.

To check the homogeneity of the sample material after AAA extraction, a second aliquot was taken from the clay fraction of KIA-46834. From the silt fraction of KIA-46835, 3 aliquots were measured (Table 1). The clay fraction of KIA-46834 is highly organic $(21 \%$ and $27 \% \mathrm{C})$ and the repeat measurement shows a very good agreement with the younger of the 2 targets of the first combustion (difference $0.3 \sigma$ ). A weighted average of $3290 \pm 15 \mathrm{yr} \mathrm{BP}$ is statistically compatible with all 3 measurements. The silt fraction of KIA-46835 contains little organic matter. Usually, the first aliquot taken from a prepared sample is enriched in organic matter (here $2.2 \% \mathrm{C}$ ), which settles on top of the mineral sediment $(1.3 \% \mathrm{C}$ in the second and third aliquot). The first and third measurements give a statistically good agreement, while the second is older. The sensitivity of a measured age to admixture of old reworked carbon increases with decreasing carbon content, which could explain at least part of the older ages obtained for the second and third aliquot, while also uneven distribution of differently aged organic fractions may have contributed. In Figure 1, we use the arithmetic mean for all fractions, because the discrepancies were relatively small compared to the age differences between the fractions and samples.

The sediment was very organic, as can be seen in Table 1 . The gravel-sized fraction $(>2 \mathrm{~mm})$ dated was almost purely organic. This is evident from the $\mathrm{C}$ content of the chemically cleaned residue of both identified macro-remains and the bulk gravel fractions, which was calculated from the gas pressure of the combusted material to be around $60 \%$. The fairly high carbon content of $11-30 \%$ of the dated sand- and clay-sized fractions implies a low sensitivity for the admixture of old carbon associated with the sediment and, thus, favorable conditions for ${ }^{14} \mathrm{C}$ dating. Only the silt fractions are mostly mineral-rich. 


\section{Rothacker et al.}

Table $1{ }^{14} \mathrm{C}$ results from 4 different samples, each divided into 5 grain-size fractions.

\begin{tabular}{|c|c|c|c|}
\hline Fraction & Age (yr BP) & C weight (mg) & Carbon content $(\%)$ \\
\hline \multicolumn{4}{|l|}{ ID: KIA-46836 Depth: $3.38 \mathrm{~m}$} \\
\hline Gravel (mixture) & $1960 \pm 30$ & 0.8 & 59 \\
\hline Sand & $2340 \pm 20^{\mathrm{a}}$ & 1.8 & 11 \\
\hline Silt & $2590 \pm 20^{\mathrm{a}}$ & 3.0 & 5 \\
\hline Clay & $2635 \pm 15^{\mathrm{a}}$ & 21.8 & 16 \\
\hline$<0.45 \mu \mathrm{m}$ & $2650 \pm 25$ & 1.8 & - \\
\hline \multicolumn{4}{|c|}{ ID: KIA-46833 Depth: $4.31 \mathrm{~m}$} \\
\hline Gravel (selected twig) & $2735 \pm 35$ & 0.8 & 61 \\
\hline Sand & $2720 \pm 25$ & 5.9 & 30 \\
\hline Silt & $3160 \pm 30$ & 9.7 & 3 \\
\hline Clay & $7130 \pm 25^{\mathrm{a}}$ & 17.0 & 12 \\
\hline$<0.45 \mu \mathrm{m}$ & $3805 \pm 30$ & 1.8 & - \\
\hline \multicolumn{4}{|l|}{ ID: KIA-46834 Depth: $4.39 \mathrm{~m}$} \\
\hline Gravel (selected willow leaf) & $2605 \pm 40$ & 0.6 & 69 \\
\hline Sand & $3010 \pm 20^{\mathrm{a}}$ & 2.5 & 17 \\
\hline Silt & $2965 \pm 35$ & 2.9 & 5 \\
\hline \multirow[t]{3}{*}{ Clay } & $3250 \pm 25$ & 21.4 & 21 \\
\hline & $3340 \pm 25$ & 21.4 & 21 \\
\hline & $3260 \pm 40$ & 0.7 & 27 \\
\hline$<0.45 \mu \mathrm{m}$ & $3090 \pm 25$ & 3.6 & - \\
\hline \multicolumn{4}{|c|}{ ID: KIA-46835 Depth: $4.65 \mathrm{~m}$} \\
\hline Gravel (mixture) & $3145 \pm 30$ & 1.1 & 59 \\
\hline Sand & $3315 \pm 20^{\mathrm{a}}$ & 2.0 & 14 \\
\hline \multirow[t]{3}{*}{ Silt } & $3575 \pm 30$ & 1.3 & 2.2 \\
\hline & $3770 \pm 40$ & 0.8 & 1.3 \\
\hline & $3610 \pm 40$ & 0.9 & 1.3 \\
\hline Clay & $3665 \pm 15^{\mathrm{a}}$ & 19.5 & 16 \\
\hline$<0.45 \mu \mathrm{m}$ & $3260 \pm 25$ & 3.3 & - \\
\hline
\end{tabular}

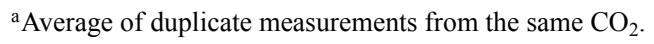

Unexpectedly, the selected fragment of willow leaf of KIA-46834 at $4.39 \mathrm{~m}$ was dated $130 \pm 53 \mathrm{yr}$ younger than the selected twig of KIA-46833 at $4.31 \mathrm{~m}$. Considering the fragility of the willow leaf, its age is most likely directly associated with the deposition of the sediment at $4.39 \mathrm{~m}$. The older twig at $4.31 \mathrm{~m}$ must then have been reworked before deposition in the sediment. The other 2 samples $>2 \mathrm{~mm}$, consisting largely of unidentifiable plant debris, give stratigraphically plausible ages. They may, however, contain remnants of water plants and, hence, could be dated older due to a hardwater effect in this limnic material. With the exception of KIA-46833, the sand-sized fractions date significantly older than the $>2$-mm fraction, which again may be attributable to an increased contribution of limnic material. The very high carbon content of the KIA- 46833 sand fraction, combined with the reworked twig, may have resulted in a (fortuitous) perfect agreement between the dates for the gravel and sand fraction.

Figure 1 generally shows an increase in measured ${ }^{14} \mathrm{C}$ age with decreasing grain size. However, the smallest grain size $(<0.45 \mu \mathrm{m})$ does not provide the oldest ages, since it may include dissolved organic matter that can move with groundwater into deeper layers. KIA-46833 forms an exception to the rule, with a gravel and sand fraction of similar age, presumably due to a reworked gravel fraction (selected twig). In addition, its clay fraction is 4000 or more years older than its gravel/sand/silt- 


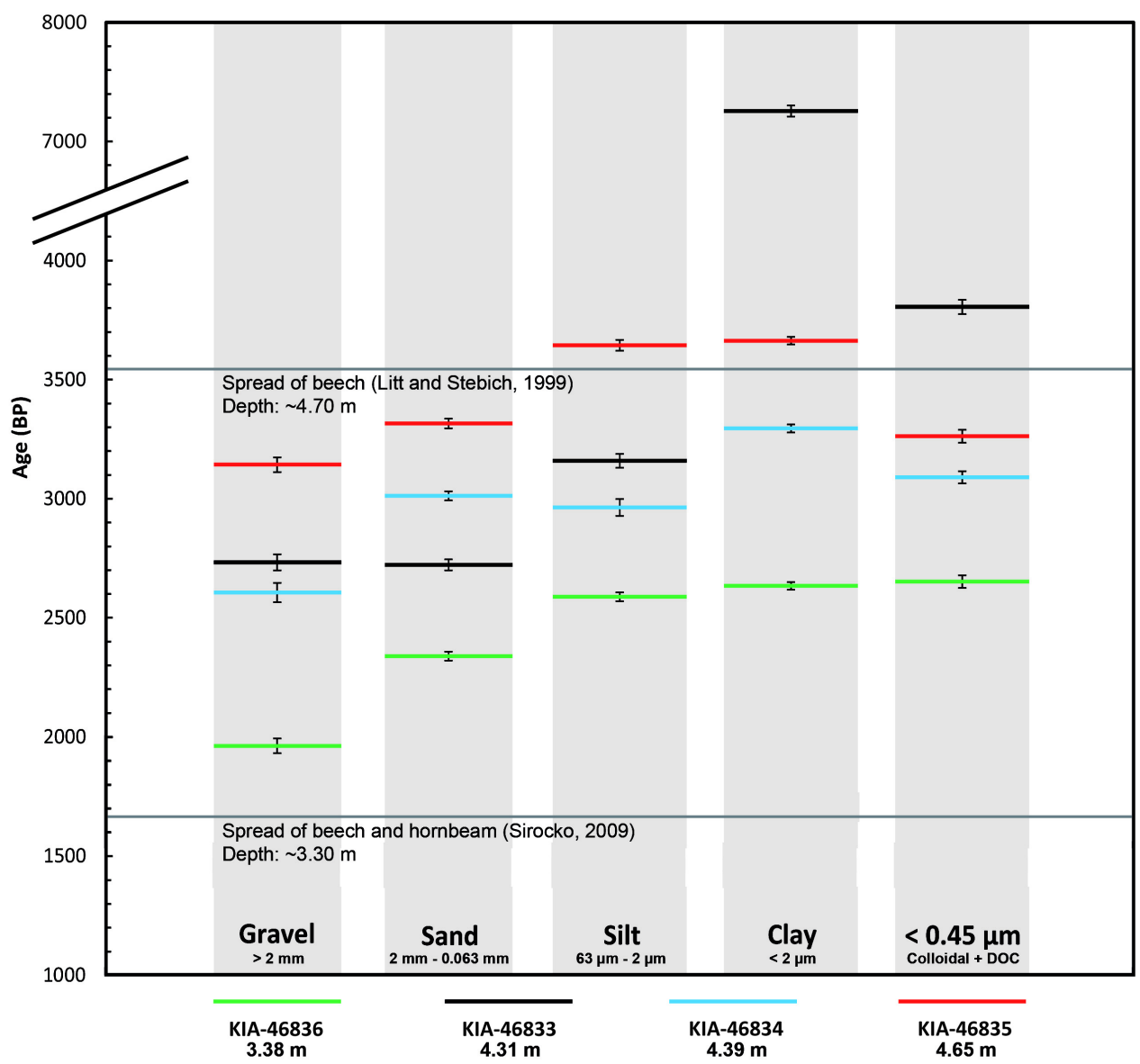

Figure $1{ }^{14} \mathrm{C}$ dates from different grain-size measurements. Colors indicate individual samples obtained from bulk sediment, at 4 given depths. Grain-size fractions show a clear trend with smaller fractions providing older ${ }^{14} \mathrm{C}$ ages. Gravel fractions show the youngest age, except for KIA-46833, sharing the youngest age with the sand fraction. The spread of beech and of beech and hornbeam in the pollen profile provides 2 chronostratigraphic markers.

sized fractions. The clay fraction has been measured twice on targets prepared from the same combusted $\mathrm{CO}_{2}$ sample with $17 \mathrm{mg}$ of carbon, producing ages differing by $72 \pm 46 \mathrm{yr}, \sim 1.6 \sigma$, and indicating good reproducibility. The high age obtained for the $<0.45-\mu \mathrm{m}$ fraction probably reflects the contribution of colloidal particles with carbon similar to that of the clay fraction. The age of the silt fraction of KIA-46834 is slightly younger than the age of the sand fraction $(45 \pm 40 \mathrm{yr}, \sim 1.1 \sigma)$.

Figure 1 shows the age heterogeneity of the organic material contained in these limnic sediments. To judge which ages are more trustworthy, some general considerations can be used. Throughout the profile, reworked sediment containing old carbon is much more likely than young particulate material infiltrating deeper grounds in these lake sediments. Yet, the high carbon content of the different fractions indicates that input of material eroded from the watershed was limited and, thus, also the contribution of reworked old carbon. Considering the volcanic setting, hardwater effects, which lead in many lakes to old ages for plants, phyto- and zooplankton, and animals living in the lake, are a more likely cause of the high measured ${ }^{14} \mathrm{C}$ ages. In the center of large, deep lakes, planktonic biomass may be the main component entering the sediment, mainly in the smaller size fractions. Gen- 


\section{Rothacker et al.}

erally, contaminations making the lake sediment older than the expected age are much more common than contamination resulting in younger ages. Therefore, the youngest fraction of each sample is assumed to be the best estimate for the time of deposition (Sirocko et al. 2013).

As indicated in Figure 1, independent time control is provided by the pollen records of the Gemündener Maar (Sirocko et al. 2013; Rothacker and Sirocko, forthcoming). Litt and Stebich (1999) investigated several maar lake sediment cores and found similarities in palynological findings, with a spread of beech around $3540{ }^{14} \mathrm{C} \mathrm{yr} \mathrm{BP}$ and a spread of beech and hornbeam around $1660{ }^{14} \mathrm{C} \mathrm{yr}$ BP. These ages can also be applied to the Gemündener Maar pollen profile, where around a depth of $4.70 \mathrm{~m}$ an increase in beech and around $3.30 \mathrm{~m}$ an increase in beech and hornbeam is recorded (Sirocko 2009). This implies that the 8-cm range between the beech/hornbeam increase at $1660{ }^{14} \mathrm{C}$ $\mathrm{yr} \mathrm{BP}$ and $3.30 \mathrm{~m}$ depth and the measured gravel fraction from KIA-46836 at $3.38 \mathrm{~m}$ accounts for $\sim 300$ yr of sedimentation, which is unlikely. Assuming constant sedimentation between KIA-46835 at $4.65 \mathrm{~m}$ and KIA-46836 at $3.38 \mathrm{~m}$ yields a sedimentation of $\sim 1.07 \mathrm{~mm}$ per year. The $8 \mathrm{~cm}$ could thus represent $\sim 75 \mathrm{yr}$, which would make the measured age of the gravel fraction $\sim 200 \mathrm{yr}$ too old, most likely due to inclusion of limnic material. On the other hand, even with this offset, it shows that the measured macro-remain mixture (KIA-46836) still provides the best estimate for the time of sedimentation, followed by the sand fraction. The second chronological marker around $4.70 \mathrm{~m}$ and $\sim 3540{ }^{14} \mathrm{C}$ yr BP suggests the age obtained for the macro-remain mixture $>2 \mathrm{~mm}$ for KIA-46835 at $4.65 \mathrm{~m}$ is $\sim 350 \mathrm{yr}$ too young.

Carbon associated with the clay fraction yields the oldest ${ }^{14} \mathrm{C}$ ages, as also observed by McGeehin et al. (2001). In general, the amount of carbon associated with clay and silt particles is mainly affected by the sediment texture and its specific surface area (i.e. type of mineral), with a high specific surface area adsorbing more organic substances than a small one (Hassink 1997). Similarly, in terrestrial soils, the clay fraction tends to store the highest proportion of carbon compared to other grain-size fractions (Jolivet et al. 2006; Quénéa et al. 2006). In an open system, such as a soil, a large carbon pool can result in a longer mean residence time, causing a depletion in ${ }^{14} \mathrm{C}$ when dating the smaller, organic-rich grain-size fractions. Limnic sediments and soils contain, in addition to adsorbed organic compounds, free particulate organic matter. For coarser grain sizes of limnic sediments (gravel and sand), this organic debris is most likely contemporaneous with the time of sedimentation. The finer fractions, mostly the clay, may also contain reworked terrestrial organic material and planktonic biomass with a potential reservoir age. These are thus likely to result in older apparent ages (cf. Törnqvist et al. 1992). The offset, moreover, can be quite variable, depending on the balance between fresh and reworked fine detritus, the limnic productivity, and the ${ }^{14} \mathrm{C}$ concentration of the lake waters, and thus on local geology and hydrology. The very old age obtained for the clay fraction at $4.31 \mathrm{~m}$ may thus reflect a very high input of planktonic biomass, either direct, or older from a sediment slump, or a temporary increased contribution of volcanic $\mathrm{CO}_{2}$ to the lake waters. Holocene maar lake sediments from the Eifel region in Germany are highly enriched in the smaller grain-size fractions such as silt and clay. Considering the fairly high carbon content of clay fractions $(12-21 \% \mathrm{C})$, dating whole sediments that are enriched in clay would result in ${ }^{14} \mathrm{C}$ ages much older than the actual time of deposition.

If the limnic sediment layer to be dated does not contain identifiable terrestrial macro-remains, a standard sieving scheme may be used to separate out gravel and sand-size fractions, which are less likely to contain planktonic and reworked material, and thus may be expected to produce ages more related to their time of deposition. The carbon content of the sediment and its distribution over the different size fractions, as well as the age of the humin of the different size fractions after chemical 


\section{Dating Bulk Sediments Using Grain-Size Approach}

cleaning, should be considered in evaluating the significance of the ages obtained for the time of deposition of the sediment.

\section{CONCLUSIONS}

${ }^{14} \mathrm{C}$ ages of separated grain-size fractions from an organic-rich limnic sediment core from the Gemündener Maar show a clear size-dependent trend, suggesting that coarser grain-size fractions provide better estimates for the time of deposition than smaller fractions. The results of this small data set support the original working hypothesis. Yet, they also show that even highly organic coarse fractions are likely to give only an approximation of the time of sedimentation instead of the true sediment age. Identifiable fragile terrestrial macro-remains, selected from the gravel fraction, can be expected to provide reliable ages. Considering the complex mixture of organic material that may be found in limnic sediments, and in sediments and soils in general, several dates are needed to establish whether a trustworthy age for the sediment layer can be obtained, if such macro-remains cannot be found.

\section{ACKNOWLEDGMENTS}

The authors would like to thank the Department of Sedimentology at the University of Mainz and the Leibniz Laboratory for Radiometric Dating and Isotope Research for the financial support, Dr Oliver Nelle from the Institute for Ecosystem Research at the University of Kiel for identifying macro-remains, Dr Ingeborg Levin from the Institute of Environmental Physics in Heidelberg for providing recent ${ }^{14} \mathrm{CO}_{2}$ measurements, the reviewer for critical comments that helped improve the paper, and the whole Leibniz-Laboratory team for support.

\section{REFERENCES}

Abbott MB, Stafford Jr TW. 1996. Radiocarbon geochemistry of modern and ancient Arctic lake systems, Baffin Island, Canada. Quaternary Research 45(3):300-11.

Amelung W, Zech W, Zhang X, Follett RF, Tiessen H, Knox E, Flach KW. 1998. Carbon, nitrogen, and sulfur pools in particle-size fractions as influenced by climate. Soil Science Society of America Journal 62(1): 172-81.

Bruns M, Levin I, Münnich KO, Hubberten HW, Fillipakis S. 1980. Regional sources of volcanic carbon-dioxide and their influence on ${ }^{14} \mathrm{C}$ content of presentday plant material. Radiocarbon 22(2):532-6.

Dreves A. 2008. C-Dynamik in Böden unter forst- und landwirtschaftlicher Nutzung - Untersuchungen mittels Radiokohlenstoff $\left({ }^{14} \mathrm{C}-\mathrm{AMS}\right)$ [PhD thesis]. Christian-Albrechts-University Kiel. 203 p.

Godwin H. 1951. Comments on radiocarbon dating for samples from the British Isles. American Journal of Science 249(4):301-7.

Grootes PM, Nadeau MJ, Rieck A. 2004. ${ }^{14}$ C-AMS at the Leibniz-Labor: radiometric dating and isotope research. Nuclear Instruments and Methods in Physics Research B 223-224:55-61.

Hassink J. 1997. The capacity of soils to preserve organic $\mathrm{C}$ and $\mathrm{N}$ by their association with clay and silt particles. Plant and Soil 191(1):77-87.
Hiller A, Tinapp C, Grootes PM, Nadeau M-J. 2003. Ungewöhnliche Probleme bei der ${ }^{14} \mathrm{C}$-Datierung organischer Komponenten und Fraktionen fluviatiler Sedimente aus der Aue der Weißen Elster bei Leipzig. Eiszeitalter und Gegenwart 52:4-12.

Jolivet C, Angers DA, Chantigny MH, Andreux F, Arrouays D. 2006. Carbohydrate dynamics in particlesize fractions of sandy spodosols following forest conversion to maize cropping. Soil Biology and Biochemistry 38(9):2834-42.

Litt T, Stebich M. 1999. Bio- and chronostratigraphy of the Lateglacial in the Eifel region, Germany. Quaternary International 61(1):5-16.

MacDonald GM, Beukens RP, Kieser WE. 1991. Radiocarbon dating of limnic sediments: a comparative analysis and discussion. Ecology 72(3):1150-5.

McGeehin J, Burr GS, Jull AJT, Reines D, Gosse J, Davis PT, Muhs D, Southon JR. 2001. Stepped-combustion ${ }^{14} \mathrm{C}$ dating of sediment: a comparison with established techniques. Radiocarbon 43(2A):255-61.

Nadeau M-J, Schleicher M, Grootes PM, Erlenkeuser H, Gottdang A, Mous DJW, Sarnthein JM, Willkomm H. 1997. The Leibniz-Labor facility at the Christian-Albrechts University, Kiel, Germany. Nuclear Instruments and Methods in Physics Research B 123(1-4): 22-30.

Nadeau M-J, Grootes PM, Schleicher M, Hasselberg P, 


\section{Rothacker et al.}

Rieck A, Bitterling M. 1998. Sample throughput and data quality at the Leibniz-Labor AMS facility. Radiocarbon 40(1):239-45.

Quénéa K, Largeau C, Derenne S, Spaccini R, Bardoux G, Mariotti A. 2006. Molecular and isotopic study of lipids in particle size fractions of sandy cultivated soil (Cestas cultivation sequence, southwest France): sources, degradation, and comparison with Cestas forest soil. Organic Geochemistry 37(1):20-44.

Rethemeyer J. 2004. Organic carbon transformation in agricultural soils: radiocarbon analysis of organic matter fractions and biomarker compounds $[\mathrm{PhD}$ thesis]. Christian-Albrechts-University Kiel. 148 p.

Rethemeyer J, Grootes PM, Bruhn F, Andersen N, Nadeau M-J, Kramer C, Gleixner G. 2004. Age heterogeneity of soil organic matter. Nuclear Instruments and Methods in Physics Research B 223-224:521-7.

Rothacker L, Sirocko F. Forthcoming. Evaluation of flood events in three Eifel Maar sediment records during the 16th century BC. In: $1600-$ Kultureller Umbruch im Schatten des Thera-Ausbruchs? 4. Mitteldeutscher Archäologentag vom 14. Bis 16. Oktober 2011 in Halle (Saale). Tagungen des Landesmuseums für Vorgeschichte Halle 9. Volume 8.
Scharpenseel HW, Becker-Heidmann P. 1992. Twentyfive years of radiocarbon dating soils: paradigm of erring and learning. Radiocarbon 34(3):541-9.

Schöning I, Kögel-Knabner I. 2006. Chemical composition of young and old carbon pools throughout Cambisol and Luvisol profiles under forests. Soil Biology and Biochemistry 38(8):2411-24.

Sirocko F. 2009. Wetter, Klima, Menschheitsentwicklung. Von der Eiszeit bis ins 21. Jahrhundert. Darmstadt: Theiss.

Sirocko F, Dietrich D, Veres D, Grootes PM, SchaberMohr K, Seelos K, Nadeau MJ, Kromer B, Rothacker L, Röhner M, Krbetschek M, Appleby P, Hambach U, Rolf C, Sudo M, Grim S. 2013. Multi-proxy-dating of Holocene maar lakes and Pleistocene dry maar sediments in the Eifel, Germany. Quaternary Science 62: 56-76.

Stuiver M, Polach HA. 1977. Discussion: reporting of ${ }^{14} \mathrm{C}$ data. Radiocarbon 19(2):355-63.

Törnqvist TE, De Jong AFM, Oosterbaan WA, Van der Borg K. 1992. Accurate dating of organic deposits by AMS ${ }^{14} \mathrm{C}$ measurements of macrofossils. Radiocarbon 34(3):566-77. 